\title{
Fertilizers Effect Blue Green Algae and increasing their Toxins
}

\author{
Ahmed Ibrahim Jessim \\ Ministry of Higher education, Scientific Research, Science and Technology Treatment and disposal of chemical, biological \\ and military hazardous wastes Center for research and development. Baghdad, Iraq
}

\section{Corresponding Author}

Ahmed Ibrahim Jessim

e-mail:ahm_jas71@yahoo.com

\author{
Article History \\ Article ID: AR1876a \\ Received in $28^{\text {th }}$ May, 2018 \\ Received in revised form $01^{\text {st }}$ June, 2018 \\ Accepted in final form $07^{\text {th }}$ June, 2018
}

\begin{abstract}
Urban activities add pollutants to the environment, and increase Phosphorous [P], Nitrogen [N], Sulfate [S] and Iron [Fe], these pollutants in Aquatic environment can cause Eutrophication of Blue green algae (BGA), which they are an auto nutrition organisms via photosynthesis and organic materials, prokaryotic and they have not specialized organelles and produce phycocyanin pigment which it's just in cyanobacteria, which have been recognized in different environments such as Antarctica below $0^{\circ} \mathrm{C}$ also in spring. Many species can produce toxic substances which they are secondary metabolic products, formed by cyanobacteria, these toxins can cause humans toxication, in different parts of the world which is an evidence of algal toxins accumulation in treated drinking fresh water, and can cause neurosystem illness and digestion system especially Hepatic also dermatitis, algal toxins represent an international problem in all water types salty, brackish and fresh water, also can be produced by terrestrial species. These types of toxins found in all types of waters fresh, brackish and salty waters. Most of these toxins are carcinogenic, many countries needs to go on to monitor this phenomenon and limitation of toxic species with fixation of routine tests for drinking water. Impact of health in more by exposure to the toxins and keep water safety imposes its presence through the permanent observer and early monitoring. Non floating algae on the surface of water let us judge on being free of algae. Sometimes one alga can produce more than one type of toxins and many species can produce one type of toxin.
\end{abstract}

Keywords: Fertilizers, BGA, algal toxins, hepatotoxins, neurotoxins, dermatoxins, endotoxins

\section{Introduction}

Urban activities had relies a lot of ecological pollutants as a by-products such as pesticides and fertilizers (Abbasi et al., 2014). Hence a long time ago, where the human concerned to develop productivity and increasing of his crops, via addition minerals and organic materials. This situation continued until the end of the sixteenth century, where this subject has become somewhat experimental (Kakhia, 2011). According to several factors was distributed between coincidence or error and right, animal organic wastes and additive substances to agricultural soils, led to an increase in plant growth clearly (Hossain et al., 2017). From used material at this period was bone powder, plant ash, animal manure and potassium powder $\left(\mathrm{KNO}_{3}\right)$ (Kilmer, 1979). but the results were very different. Some treatments did not give the desired results from one field to another (Roy et al., 2006). It is worth mentioning that we refer to the attempts of Van Helmont in Belgium, as he planted a cleft of willow (Salix fragilis) and used only rain water in irrigation or ground water, one of the first attempts to improve plant production, but at 1660 , Digby succeed in using salt gunpowder as a fertilizer for arid lands in agriculture. But Liebig at 1840 established the basis of modern fertilizer industry, in turn confirmed that these materials are replenished soil, Liebig realized the importance and value of nitrogen $\mathrm{N}$ plants, but he was convinced that plants can get their nitrogen $\mathrm{N}$ through the air and not through the soil (Kakhia, 2011). Production of fertilizers was developed at the first quarter of $19^{\text {th }}$ century (Savci, 2012), powders of animal bones were used and added to the plants, there are traces and evidences that human bones were collected from cemeteries, from battlefields and even the bones of dead animals in that period, they were crushed and added to the plantings (Kilmer, 1979), but at 1830 Sulfuric acid $\mathrm{H}_{2} \mathrm{So}_{4}$ was added to the bone with distribution on the farm by wood drums. In the same period of time, Potassium salts, Ammonium sulphate $\left(\mathrm{NH}_{4}\right)_{2} \mathrm{So}_{4}$ or Sodium nitrate $\mathrm{NaNO}_{3}$ were sometimes added to plants, then he introduced first mixed liquid of chemical fertilizer. Fertilization is considered as one of the most important conditions for increasing efficiency of agricultural lands and one of the most important methods to increase the fertility of agricultural land and raise the productivity of agricultural crops. Chemical fertilizers mainly contain phosphates, nitrates, ammonium and potassium salts (Svaci, 2012). The fertilizer industry is a very important source of natural radionuclide's and heavy metals as potential sources of crops. It also contains most heavy metals such as 
mercury, cadmium, lead, copper and nickel (Atfar et al., 2010). Moreover, it contains natural radionuclides such as uranium U238, Thorium TH232 and Polonium Po 1-2210 (Chauhan and Kumar, 2015; Savaci, 2012). However, the growth and consumption of plant fertilizers has increased dramatically worldwide, with increasing environmental problems such as accumulation of heavy metals in soils and plants (Atfar et al., 2010). It is possible that environmental pollutants reach the food chain, and because of fertilization there is deterioration in the quality of water, soil and air as a result of manufacturing processes, so there are countries that have regularized the use of chemical fertilizers such as some developing countries and Turkey where its considered as least country in using chemical fertilizers per hectare, which use $100.4 \mathrm{~kg} \mathrm{ha}^{-1}$ of NPK, but the highest is Netherlands, which use $624.8 \mathrm{~kg} \mathrm{ha}^{-1}$. (Svaci, 2012). Increasing of agricultural production is considered as global phenomenon, and the increasing of crops depends to a large extent on the types of fertilizer which used as nutrient supplements to the plants due consumption of some plants in their previous growth in the fields of food needed for their growth due to the consumption of some of the plants for nutrients in their previous growth at the fields, as well as increasing, maximizing productivity and economic returns (Conforti, 2011). It is also necessary to consider the environmental impact of these additives (chemical fertilizers) on the soil, animals and insects that are necessary living in the soil, also taking into consideration the effect of climate directly on these materials and their effectiveness on both of soil and living organisms, where these organisms effect directly in formation of organic waste fertilizers of the soil (Rai et al., 2014). In addition to that waste water which reach with organic and inorganic materials which increase many problems, one of these problems is Eutrophication, quality of fresh water and impacts of public health due to due excretion alkaline toxic and carcinogenic materials, also can cause diseases such as syndromes related with neurosystem, digestive system and allergy (Bitton, 2014). Although green and blue green algae reached water with Oxygen $\mathrm{O}_{2}$ in natural growth, but they exhaust nutrients of nutrients of another organisms and oxygen. Algae have high ability to live in different aquatic environments, where they can tolerate a range of temperatures beginning from $0{ }^{\circ} \mathrm{C}$ to high temperatures which giving them a good chance of growth and reproduction naturally (Whitton, 1992), due to availability of important plant nutrients such as Nitrogen $(N)$ and Phosphorus $(\mathrm{P})$, in addition to that salts, minerals and micro nutrients which they are necessary for growth and reproduction (DalCorso et al., 2014). Algae can grow to over-growth and their appearance on the surfaces of water bodies many times, also they can produce a massive quantities of biomass which can cause heavy losses in the production of fish and livestock's (Khan and Mohammad, 2014), in addition to the impact on public health and can be collected at the bottom of the body or water side margins and there is difficulty in dispersion at that gathering toxins in freshwater (Chorus and Bartram,
1999). These toxins can be classified in four main groups which they Hepatotoxin, Neurotoxins, Dermatoxins and Endotoxins (Funari and Testai, 2008). The produced algal toxins by bluegreen algae are alkaloid chemical compounds that accumulate in the tissues of fish and other aquatic organisms (Jung et al., 2003). Some of cyanotoxins such as Neurotoxins target the neuromuscular system, paralysing peripheral, skeletal and respiratory muscles with different mechanisms (Zaccaroni and Scaravali, 2008). Toxication with these toxins depend on intensity of consumed toxins amount (Funari and Testai, 2008). Some of blue green algae toxins due to their structure contained an amino acids (Mankiewicz et al., 2003), but others are very close to carbamate compounds, especially Organphosphorus pesticides (Patocka et al., 2011). These toxins cannot effected by increasing of temperature in aquatic ambient also aggregate in water bodies therefore they impact public health, bird's health and domestic animals which consume polluted water, also production of cyanotoxins linked with temperature (Holland and Kinnear, 2013). Efforts have been combined around the world for monitoring and determining how to minimize economical and public health impacts of algae to keep environment from deteriorating especially in the quantities of scarce water (EEA, 2011). The leaking of untreated wastewater to the waters bodies can increase massive algal growth up to the extent of environmental impacts via depleting oxygen and cause lake of enough light access to the water body and impact sustainability of biodiversity which leads to massive losses reaching massive density, less individuals of cyanobacteria in water body may occur to bloom if conditions helps for increasing Eutrophication (Smith, 2003). If cyanobacteria grew in water bodies at the case of Eutrophication it possible to spread on the surface of water bodies via winds and water streams then may cover surface in some times and threats water body and living organisms which live in (WHO, 2016).

\section{Blue Green Algae (Cyanobacteria)}

Blue green algae (BGA) considered as oldest group had been lived in wide range of temperature from 35 ㄷ $\mathrm{C}$ in worm areas to below 0 ㄷ $\mathrm{C}$ in Antarctica (Whitton, 1992). BGA can produce toxins as a secondary natural metabolism products, these toxins are different in toxicity from species to the others and ifferent in impacts upon health and economic (Zain, 2011), less toxicity can cause dermatitis and highly toxic to liver Hepatotoxic. Active BGA toxins are global phenomenon in fresh waters, marine's wagers and brackish waters, also it may can produces via terrestrial species of BGA. At last decades the numbers of BGA increased, there for toxicity accidents increased also. Analyses at laboratories and active methods to detect toxicity of BGA, depend on natural samples and $B G A$ isolation in laboratory to manage waters to decrease growing of toxic BGA mass, need to understand how to produce toxins, toxins proprieties and paths of exposure which shows health impacts to prevent or reducing of BGA toxins 
impacts (Dellinger, et al., 2017; Zaccaroni and Scaravali, 2008; Hitzfeld et al., 2000b). Toxins producers algae are unicellular microscopic organisms, auto nutrition via photosynthesis and organic materials. BGA have a different in general properties from another species of algae and bacteria, therefore they are behave like plants in another hand behaves like bacteria because cellular contains similar to cellular contains of bacterial cell, where its cellular wall has no cellulose, reproduce asexually, prokaryotic and they have not specialized organelles and produce phycocyanin pigment which it's just in cyanobacteria, due to that BGA have blue color and called Cyanobacteria, some of these toxic types are Microcystins, Anabaena, Nostoc and Planktothrix (Dellinger et al., 2017).

Cyanobacteria are very important microorganisms to study because they are in period of blooming responsible about many risks and his animal and aquatic resources such as fish, water birds and another aquatic animals due to producing toxins which accumulate in animals and birds bodies, blooming of Cyanobacteria evidence about increasing of Cyanobacteria toxins concentrations to Dangerous levels on humans and animals alike (Chorus and Bartram, 1999). These toxins also impacts all companied organisms in aquatic environment like zooplankton which feeding on phytoplankton, invertebrate and all vertebrate, also impact fish directly and indirectly due to direct feeding on zooplankton which feeding on Cyanobacteria. And direct impact due to eutrophication where organs of animals like liver, kidney and gills by Cyanobacteria (Zaccaroni and Scaravali, 2008). Each type of toxin probably produced by more than one type of Cyanobacteria, and they can produce one type of toxin by many types of Cyanobacteria (Funari and Testai, 2008). In (Table 1). In different types have a variable genotype, some of them has responsible gene to produce toxins others have not this gene (Kurmayer et al., 2002). The toxicity combined with produce different Cyanobacteria toxins (An and Carmichael, 1994).

\section{Health Effects of Cyanotoxins}

Understanding of Cyanotoxins importance depend on basic researches at the levels of toxicology and toxins ambient. Also depend on recognition and verification of adverse health outcomes in Animals and humans alike (Dellinger et al., 2017). There were many cases of toxification had been reported at USA after destruction of cyanotoxins cells and realizing toxins to the aquatic ambient after chemical remediation at nature with Copper sulfate $\left(\mathrm{CuSO}_{4}\right)$, where thousands of people toxified with Cyanotoxins toxins, cases varied between simple with first aid, while others were suffering from severe died (Falconer, 2005; Tisdale, 1931). At 1996 In Zimbabwe toxification with Cyanotoxins were identified after drinking contaminated water from child's, Australia at 1983 and in Brazil at 1993 (Zaccaroni and Scaravali, 2008)

Cyanotoxins can be classified in four groups, 1) Hepatotoxins impact liver. 2) Neurotoxins impact neurosystem. 3) Dermatoxins can cause irritation of respiratory system and skin. 4) Endotoxins were reported they can cause irritation

\begin{tabular}{ll}
\hline $\begin{array}{l}\text { Table 1: Types of Cyanobacteria toxins and types of algae } \\
\text { producers }\end{array}$ & \\
\hline Cyanotoxin & Main producing cyanobacteria \\
\hline Microcystins & Most of Microcystis spp. and \\
& Planktothrix spp, some Anabaena, \\
& Nostoc and Synechocystis and \\
& Cyanobium bacillare, Arthrospira \\
& fusiformis, Limnothrix redekei, \\
& Phormidium formosum, Hapalosiphon \\
& hibernicus \\
& Nodularia spumigena \\
Nodularins & Cylindrospermopsis raciborskii, \\
Cylindrospermop & Umezakia natans, Aphanizomenon \\
sin & ovalisporum, Aphanizomenon \\
& flos-aquae, Rhaphidiopsis curvata, \\
& Anabaena lapponica, Anabaena \\
& bergii \\
& Most of Anabaena spp., some \\
& Aphanizomenon (A. flos-aquae, A. \\
& issatschenkoi), Cylindrospermum, \\
& Microcystis and Planktothrix spp. and \\
& Raphidiopsis Mediterranea \\
Anatoxin-a &
\end{tabular}

Homoanatoxin-a Oscillatoria formosa, Raphidiopsis mediterranea

Anatoxin a-(s) Anabaena flos-aquae and $A$. lemmermannii

Saxitoxins (PSP) Aphanizomenon, Anabaena, Lyngbya and Cylindrospermopsis spp.

LPS endotoxins All Cyanobacteria

Aplysiatoxin, Lyn- Lyngbya majuscula (marine waters), gbyatoxin Debro- Oscillatoria nigro-vridis moaplysiatoxin

Microviridin J Microcystis spp.

ß-N-methylamino- Microcystis, Anabaena, Nostoc Lalanine and Planktothrix spp. and most of cyanobacteria symbionts tested

of stomach and intestine (Chorus, 2005). For all planktonic algae and benthic types aggregate and become near coasts there for they concentrate, due to that they need non short time to separate, in general, therefore they cause hygienic problems to human and impact negatively economic animals. Now, many of BGA communities are highly toxic (Zaccaroni and Scaravali, 2008).

\section{Types of Cyanotoxins}

\subsection{Neurotoxins-1}

These types of toxins prevent neuronal signal via two mechanisms

\subsubsection{Anatoxins}

Higher or lesser concentrations can effect negatively 
acetylcholine and act as inhibitor of cholinesterase enzymes and cause organo phosphorous syndrome, symptoms similar to toxification with organo phosphorous pesticides (Zaccaroni and Scaravali, 2008). It's one of major groups of Cyanotoxins which produce by different types of BGA in fresh waters some times in case of Eutrophication as floating area near shores of reveres and lakes. Anatoxins are alkaline compounds have a fast and sever effect and cause death for a lot of livestock (Messineo et al., 2009). Now identified as three alkaline compounds Figure 1. Produced by Anabaena flosaquae, non as $\mathrm{Di}$ aromatic amin, highly toxic and can cause death during 15 minutes. It was distinguished at first as Anatoxin-a impact muscular nerves and cause death via paralysis of respiratory system (Tisdale, 1931), produced from three widespread types of BGA Aphanizomenon, Anabaena, Planktothrix (Tatters et al., 2017)

\subsubsection{Anatoxin-a(s)}

They are less widespread during algal BGA communities development and blooming in nature, however, they have been identified by tracking livestock mortality at USA (Patocka et al., 2011). Also they impact nerves in its stimulations also they are working to disrupt the flow of Sodium ions $\mathrm{Na}^{+}$and works to activate the Calcium pump ions $\mathrm{Ca}^{++}$(Soliakov et al., 1995). In structure are similar to organo phosphorous insecticides Figures (1 and 2). They are working as anticholinesterase, one of the symptoms of toxification, they causes excessive saliva from the victim's mouth (Falconer, 2005).
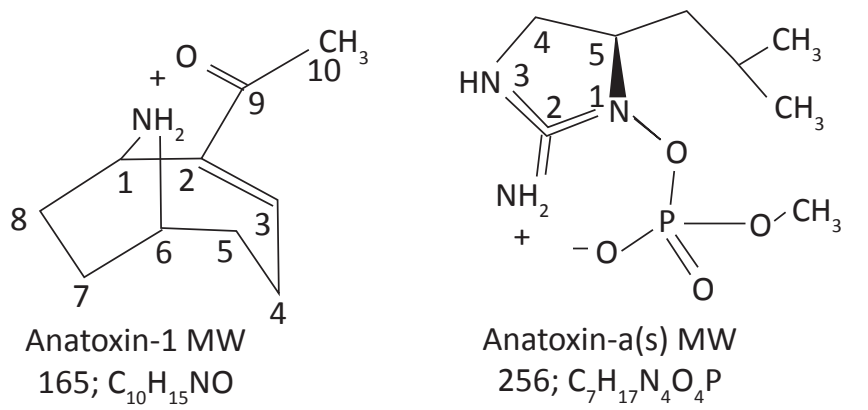

$$
\begin{gathered}
\text { Anatoxin-a(s) MW } \\
\text { 256; } \mathrm{C}_{7} \mathrm{H}_{17} \mathrm{~N}_{4} \mathrm{O}_{4} \mathrm{P}
\end{gathered}
$$

Figure 1: Structure formula of alkaline cyanotoxins from (Funari and Testai, 2008)

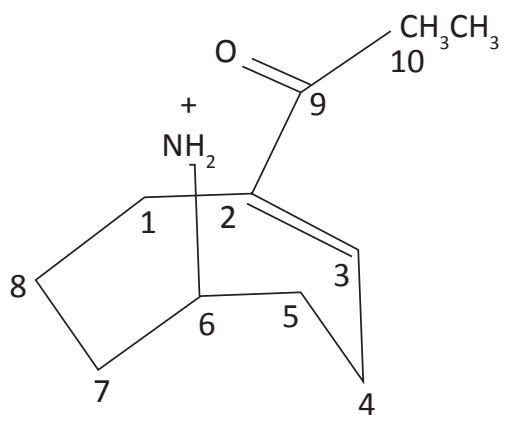

Homoanatoxin-a MW 179; $\mathrm{C}_{11} \mathrm{H}_{17} \mathrm{NO}$

Figure 2: Homoanatoxin structural formula from (Funari and Testai, 2008)
Among all Anatoxins there are just three structures were known figures (1 and 2), Anatoxin-a Anatoxin-a(s) and Homoanatoxin-a, although of similarity of names, but they aren't connected with factors of Common chemical and Homoanatoxin-a is an isomer of Anatoxin - a, also Anatoxin-a is the first toxin of BGA toxins was identified and known well as effect and chemically when discovered. Anatoxin-a highly polar and dissolved well in water, his ionic state depend on $\mathrm{pH}$. Anatoxin-a(s) is ester mono phosphate with aromatic structure formula of $\mathrm{N}$-hydroxyguanidine (Zaccaroni, and Scaravali, 2008).

\subsection{Saxitoxin}

One of known well of toxins which impact nerves and can cause Paralytic Shell Poisoning (PSP). Which directly kill a hundreds of people in different parts of world (Cirés et al., 2017). Can block Potassium $\mathrm{K}^{+}$sodium $\mathrm{Na}^{+}$pump which make unbalanced $\mathrm{Na}$ inside neurons. In some cases nerve poisoning detected via drinking of polluted water from livestock or consumption of contaminated water foam (Zaccaroni, and Scaravali, 2008). Saxitoxins not produced from BGA and marine algae only, but produces also from another BGA in fresh waters like Anabaena, Aphanizomenon and Lyngbya (Falconer et al., 1983; Velzeboer et al., 2000). Saxitoxins are characterized stable and fixed molecules even in the case of heating and not easy to remove from waters in classic methods unless $\mathrm{pH}$ is controlled and residual chlorine but can be removed efficiently by ozone or activated carbon (Falconer et al., 1989).

\subsubsection{Chemical structure}

Saxitoxins at least consist from a group of 19 toxin from Carbamat Alkaline Neurotoxins (CAN) which is one of the endemic neurotoxins in freshwater and brackish waters, they Inhibits nervous transport by blocking sodium channels, also this group of toxins produced from Dinoflaglite in phytoplankton community (Dellinger et al., 2017) (Figure 3).

\subsection{Cytotoxin or cylindrospermopsin}

Alkaline substance can blocking paths of producing protein

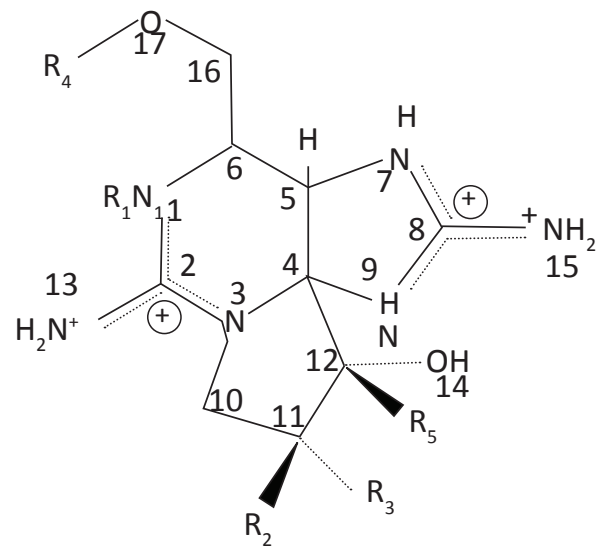

Figure 3: General structure of saxitoxins from (Funari and Testai, 2008) 
due to covering DNA or RNA, and responsible of damage of Crushing the helix of genetic material DNA for all chromosomes (Asymmetry of chromosomes) and proved as a carcinogen. The toxicity of cylindrospermopsin associated with obvious losses of glutathione and glutathione depletion leading to cell death, decreasing of glutathione rates due to blockage of general pathway to build glutathione (Zaccaroni, and Scaravali, 2008).

\subsubsection{Chemical structure}

Cytotoxin or Cylindrospermopsin is one molecule consisting from a group of aromatic Tri quandin which Includes contains Hydroxy methyl ureasil, Figure 4. Hydrophilic, easy intestinal absorption, need active transport system and has the ability to inter to the liver cells, Cylindrospermopsin can use special active transport system of bile acid, due to the size of small molecule, minor changes occur because of negative

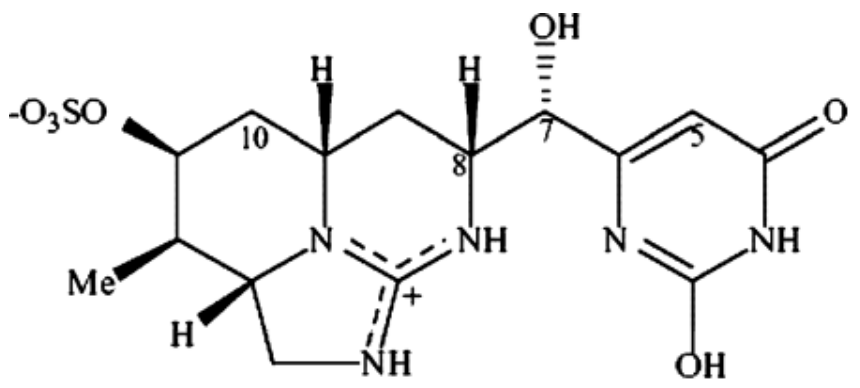

Figure 4: Chemical structure of Cylindrospermopsin from (Funari and Testai, 2008)

propagation through the bio membranes, Showing the effects of toxins inside and along the cells, not just across the channel transport system of bile acid at the liver (Chong et al., 2002). All studies in vivo (Norris et al., 2001; Norris et al., 2002), and in vitro also in primary hepatocytes cells (Runnegar et al., 1994; Runnegar et al., 1995), showed that Cylindrospermopsin was activated vitally with proteins of electronic transport P-450 (P450) (Norris et al., 2002). In addition, there are projects to prove $(\mathrm{CYN})$ is one of the cause's cancer, because there are an evidence about this opinion (Falconer and Humpage, 2001).

\subsection{Microcystins or nodularin}

Widespread more than other toxins of BGA, It works to stop the enzymes of protein phosphorylation 1 and $2 \mathrm{~A}$ and caused liver toxification in bile channels which used as a carrier of the bile to pass through cells membranes. The toxicity of Microcystins or Nodularins is more inside peritoneal cavity. Hepatic damage is a result of Microcystins at Australia (Cirés et al., 2017). Microcystins or Nodularins toxicity is cumulative toxicity, and considered as an important factors development of tumors and increase in liver also lead to human injury of hepatic tumors (Zaccaroni and Scaravali, 2008). After exposure to Microcystins-LR, the lab mice are affected 10 times more often than their consumption through oral exposure and are infected vascular lobe decomposition with damage to the lining of the respiratory tract (Fitzgeorge et al., 1994). Early in 1975 , blood decomposition found as a result of exposure to the BGA toxins via orally (Hindman et al., 1975). People are exposed to BGA toxins through the daily consumption of polluted water by drinking or exposure to them through recreation (Falconer and Humpage, 1996; Falconer, 1998).

\subsubsection{Chemical structure}

Microcystins are polypeptides associate with seven amino acids, which include 80 isomers, therefor they are considered as the most widespread of other toxins in the world, in general structure formula, all Microcystins share it as shown in figure (Dellinger et al., 2017). These amino acids are distributed as shown in the attached parts such as $\mathrm{X}, \mathrm{Z}, \mathrm{R}^{1}, \mathrm{R}^{2}$ (Butler et al., 2009) Figure 5.

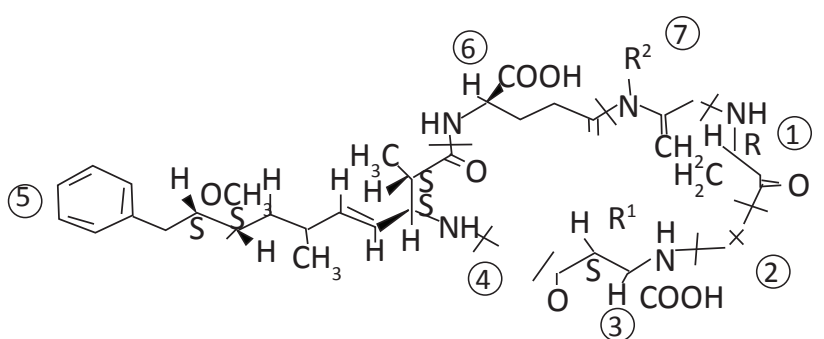

Figure 5: General structure formula from (Funari and Testai, 2008).

Numbers in the figure represent link locations of four amino acids which they distributed over seven locations, either two locations $R^{1} R^{2}$ represents two locations for two groups of methyl, for other two locations $Z$ and $X$, shows posts of four aminoacids Table 2.

An international organizations had published its report at

Table 2: Sites of amino acids in the morphological form of Microcystins

\begin{tabular}{lccc}
\hline Name & $\begin{array}{c}\text { X-position } \\
\text { amino acid }\end{array}$ & $\begin{array}{c}\text { Z-position } \\
\text { amino acid }\end{array}$ & $\begin{array}{c}\text { Molecular } \\
\text { weight }\end{array}$ \\
\hline 910.06 & Alanine (A) & Leucine (L) & Microcystin LA \\
1045.19 & Arginine (R) & Tyrosine (Y) & Microcystin YR \\
1038.2 & Arginine (R) & Arginine (R) & Microcystin RR \\
995.17 & Arginine (R) & Leucine (L) & Microcystin LR \\
\hline
\end{tabular}

1999 and reported variability of Microcystins (Falconer, 1998). As shown in Table 3. which refer to these Microcystins and there 60 isomers .

In order to what reported in Table 3. Some formulas of Microcystins have been partially described (Butler et al., 2009; Sivonen and Jones, 1999; Boland et al., 1993; Craig et al., 1993). From many scientific projects found most of Microcystins even if they vary, they are very toxic and 50$300 \mu \mathrm{g}$ highly toxic to mice (Jones et al., 1995; Harada et al., 1990a). But few of Microcystins isomers are found non-toxic (Harada et al., 1990b). Recently, and more obvious there are 80 isomers of Microcystins where fixed from (Codd et al., 2005), and producers of them, as shown in Table 4. 


\begin{tabular}{|c|c|c|c|c|c|}
\hline Molecular Weight & Organisms & $\begin{array}{l}\text { Micro- } \\
\text { cystin }\end{array}$ & Molecular Weight & Organisms & $\begin{array}{l}\text { Micro- } \\
\text { cystin }\end{array}$ \\
\hline \multirow[t]{2}{*}{ MCYST-LA } & \multirow{2}{*}{$\begin{array}{l}\text { Microcystis aeru- } \\
\text { ginoa } \\
\text { M. viridiss }\end{array}$} & \multirow[t]{2}{*}{909} & $\begin{array}{l}\text { [D-Asp3, ADMAdda5, Dhb7] } \\
\text { MCYST-LR }\end{array}$ & Nostoc sp. & 1,009 \\
\hline & & & [L-MeSer7]MCYST-LR & Microcystis spp. & 1,012 \\
\hline MCYST-LAba & M. aeruginosas & 923 & [Dha7]MCYST-FR & Microcystis sp. & 1,014 \\
\hline MCYST-LL & M. aeruginosab & 951 & [L-Ser7]MCYSTE(OMe)E(OMe) & Anabaena sp. & 1,015 \\
\hline MCYST-AR & Microcystis spp. & 952 & [ADMAdda5]MCYST-LR & Nostoc sp. & 1,022 \\
\hline MCYST-YA & M. aeruginosas & 959 & [D-Asp3,ADMAdda5] MCYST- & Nostoc sp. & 1,022 \\
\hline \multirow[t]{2}{*}{ [D-Asp3,Dha7]MCYST-LR } & \multirow{2}{*}{$\begin{array}{l}\text { M. aeruginos } \\
\text { Anabaena sp. }\end{array}$} & \multirow[t]{2}{*}{966} & LHar & & \\
\hline & & & [D-Asp3]MCYST-RR & O. agardhiis, & 1,023 \\
\hline [D-Asp3,Dha7]MCYSTEE(OMe) & Anabaena sp. & 969 & & Anabaena sp.s, & \\
\hline MCYST-VF & M. aeruginosa & 971 & & M. aeruginosas & \\
\hline \multirow[t]{2}{*}{ (D-Asp3]MCYST-LR } & \multirow{2}{*}{$\begin{array}{l}\text { A. flos-aquae, } \\
\text { M. aeruginosas, } \\
\text { M. viridisb, } \\
\text { O. agardhii }\end{array}$} & \multirow[t]{2}{*}{980} & [Dha7]MCYST-RR & $\begin{array}{l}\text { M. aeruginosas, } \\
\text { Anabaena sp.s, } \\
\text { O. agardhiis }\end{array}$ & 1,023 \\
\hline & & & MCYST-LW & M. aeruginosas & 1,024 \\
\hline \multirow[t]{2}{*}{ [Dha7]MCYST-LR } & \multirow{2}{*}{$\begin{array}{l}\text { M. aeruginosa } \\
\text { Anabaena sp. } \\
\text { O. agardhiis }\end{array}$} & \multirow[t]{2}{*}{980} & MCYST-FR & Microcystis spp. & 1,028 \\
\hline & & & MCYST-M(O)R & Microcystis spp. & 1,028 \\
\hline \multirow[t]{2}{*}{ [DMAdda5]MCYST-LR } & \multirow{2}{*}{$\begin{array}{l}\text { Microcystis. spp. } \\
\text { Nostoc. sp. }\end{array}$} & \multirow[t]{2}{*}{980} & [Dha7]MCYST-HphR & Anabaena sp. & 1,028 \\
\hline & & & [D-Asp3, Dha7]MCYST-HtyR & Anabaena sp. & 1,030 \\
\hline [Dha7]MCYST-EE(OMe) & Anabaena sp. & 983 & [Dha7]MCYST-YR & M. aeruginosas & + \\
\hline \multirow{2}{*}{$\begin{array}{l}\text { [D-Asp3,Dha7] CYSTE(OMe) } \\
\text { E(OMe) }\end{array}$} & \multirow[t]{2}{*}{ Anabaena sp. } & \multirow[t]{2}{*}{983} & [D-Asp3]MCYST-YR & Microcystis spp. & + \\
\hline & & & MCYST-YM(O) & M. aeruginosa & 56 \\
\hline MCYST-LF & M. aeruginosa & 985 & [ADMAdda5]MCYST-LHar & Nostoc sp. & 60 \\
\hline MCYST-LR & $\begin{array}{l}\text { M. aeruginosa, } \\
\text { A. flos-aquae } \\
\text { M. viridiss }\end{array}$ & 994 & MCYST-RR & $\begin{array}{l}\text { M. aeruginosas, } \\
\text { M. viridiss, } \\
\text { Anabaena sp. }\end{array}$ & 600 \\
\hline \multirow{2}{*}{$\begin{array}{l}\text { [D-Asp3,D-Glu(OCH3)6]MCYST- } \\
\text { LR }\end{array}$} & \multirow[t]{2}{*}{ A. flos-aquaes } & \multirow[t]{2}{*}{994} & [(6Z)-Adda5]MCYST-RR & M. viridisb & $>1,200$ \\
\hline & & & [D-Ser1, ADMAdda5]MCYST-LR & Nostoc sp.s & + \\
\hline $\begin{array}{l}\text { [(6L)-Addab]MICYSI-LR } \\
\text { [Dha7]MCYST-E(OMe)E(OMe) }\end{array}$ & M. viridisb & 994 & [ADMAdda5,MeSer7]MCYST- & Nostoc sp. & + \\
\hline [L-Ser7]MCYST-LR & Anabaena sp. & 998 & [L-Ser7]MCYST-RR & & \\
\hline MCYST-LY & M. aeruginosas & 1,001 & 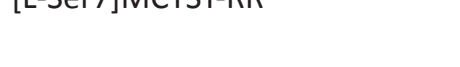 & $M$. & $T$ \\
\hline [L-Ser7]MCYST-EE(OMe) & Anabaena sp. & 1,001 & & aeruginosas/b & \\
\hline \multirow{2}{*}{$\begin{array}{l}\text { [D-Asp3,Ser7]MCYSTE-(OMe) } \\
\text { E (OMe) }\end{array}$} & \multirow[t]{2}{*}{ Anabaena sp. } & \multirow[t]{2}{*}{1,001} & [D-Asp3,MeSer7]MCYST-RR & O. agardhiis & + \\
\hline & & & MCYST-YR & M. aeruginosas, & 70 \\
\hline MCYST-HilR & Microcystis spp. & 1,008 & & M. viridiss & \\
\hline [D-Asp3,ADMAdda5]MCYST-LR & Nostoc sp. & 1,008 & [D-Asp3]MCYST-HtyR & A. flos-aquaes & $160-$ \\
\hline [D-Glu(OCH3)6]MCYST-LR & $\begin{array}{l}\text { A. flos-aguaes, } \\
\text { Microcystis sp. }\end{array}$ & 1,008 & [Dha7]MCYST-HtyR & Anabaena sp. & $\begin{array}{c}300 \\
+\end{array}$ \\
\hline \multirow[t]{2}{*}{ [D-Asp3,Dha7]MCYST-RR } & \multirow{2}{*}{$\begin{array}{l}\text { O. agardhiib, } \\
\text { Anabaena sp.s, } \\
\text { M. aeruginosas }\end{array}$} & 1,009 & MCYST-(H4)YR & Microcystis spp. & NR \\
\hline & & & $\begin{array}{l}\text { [D-Glu-OC2H3(CH3)OH6] } \\
\text { MCYST-LR }\end{array}$ & Microcystis spp. & $>1,000$ \\
\hline
\end{tabular}




\begin{tabular}{|c|c|c|}
\hline Molecular Weight & Organisms & $\begin{array}{l}\text { Micro- } \\
\text { cystin }\end{array}$ \\
\hline $\begin{array}{l}\text { [D-Asp3,ADMAdda5,Dhb7] } \\
\text { MCYST-RR }\end{array}$ & Nostoc sp. & + \\
\hline MCYST-HtyR & A. flos-aquaes & $80-100$ \\
\hline [L-Ser7]MCYST-HtyR & Anabaena sp. & + \\
\hline MCYST-WR & Microcystis spp. & $\begin{array}{l}150- \\
200\end{array}$ \\
\hline $\begin{array}{l}\text { [DAsp3, ADMAdda5,Dhb7] } \\
\text { MCYSTHtyR }\end{array}$ & Nostoc sp. & + \\
\hline [L-MeLan7]MCYST-LR & Microcystis spp. & 1,000 \\
\hline
\end{tabular}

Aba: Aminoisobutyric acid; ADMAdda: O-Acetyl-O-demethylAdda; Dha: Dehydroalanine; Dhb: Dehydrobutyrine; DMAdda: O-DemethylAdda; E(OMe): Glutamic acid methyl ester $\Delta$; (H4)Y: 1,2,3,4,-tetrahydrotyrosine; Har: Homoarginine; Hil: Homoisoleucine; Hph: Homophenylalanine; Hty: Homotyrosine; MeLan: N-Methyllanthionine; $\mathrm{M}(\mathrm{O})$ : Methionine-S-oxide; MeSer: N-Methylserine; (6Z)-Adda: Stereoisomer of Adda at the $\Delta 6$ double bond

\begin{tabular}{|c|c|c|}
\hline Toxins & $\begin{array}{l}\text { No. Vari- } \\
\text { ants }\end{array}$ & Genera \\
\hline \multicolumn{3}{|l|}{ Hepatotoxins } \\
\hline Microcystins & $80+$ & $\begin{array}{l}\text { Microcystis, Anabaena, Nostoc, } \\
\text { Anabaenopsis, Planktothrix, } \\
\text { Oscillatoria Hapalosiphon, }\end{array}$ \\
\hline Nodularins & 9 & Nodularia, Theonella \\
\hline $\begin{array}{l}\text { Cylindrosper- } \\
\text { mopsin }\end{array}$ & 3 & $\begin{array}{l}\text { Cylindrospermopsis, Anabaena, } \\
\text { Aphanizomenon, Raphidiopsis. }\end{array}$ \\
\hline \multicolumn{3}{|l|}{ Neurotoxins } \\
\hline Anatoxin-a & 5 & $\begin{array}{l}\text { Anabaena, Oscillatoria, Phormi- } \\
\text { dium, Aphanizomenon }\end{array}$ \\
\hline Anatoxin-a(s) & 1 & Anabaena \\
\hline Saxitoxins & 20 & $\begin{array}{l}\text { Aphanizomenon, Anabaena, } \\
\text { Lyngbya, Cylindrospermopsis, } \\
\text { Planktothrix }\end{array}$ \\
\hline \multicolumn{3}{|l|}{ Dermatoxins } \\
\hline $\begin{array}{l}\text { Lyngbyatoxins- } \\
\text { a }\end{array}$ & 1 & Lyngbya, Schizothrix, Oscillatoria \\
\hline Aphlysiatoxins & 2 & Lyngbya, Schizothrix, Oscillatoria \\
\hline
\end{tabular}

\subsection{Lipopolysaccharides (LPS)}

External compounds of the cellular membranes of blue green algae and gram negative bacteria, the single molecule consists of three main areas: the first is the inner region and consists of non-annular sugar, termed lipid A. a central area of fatty saccharides, associated with an internal secondary unit of specialized external carbohydrate O-specific chain figure (Zaccaroni and Scaravali, 2008)

LPS of Blue green algae BGA are differ somewhat from those evaluated by bacteria, and the difference is the appearance of very small amounts from phosphate. When exposed to these Types of toxins, the infected person will suffering from allergy, itching in the skin, allergy of eyes, irritation of digestive system and severe diarrhea in advanced cases (Funari and Testai, 2008) (Figure 6).

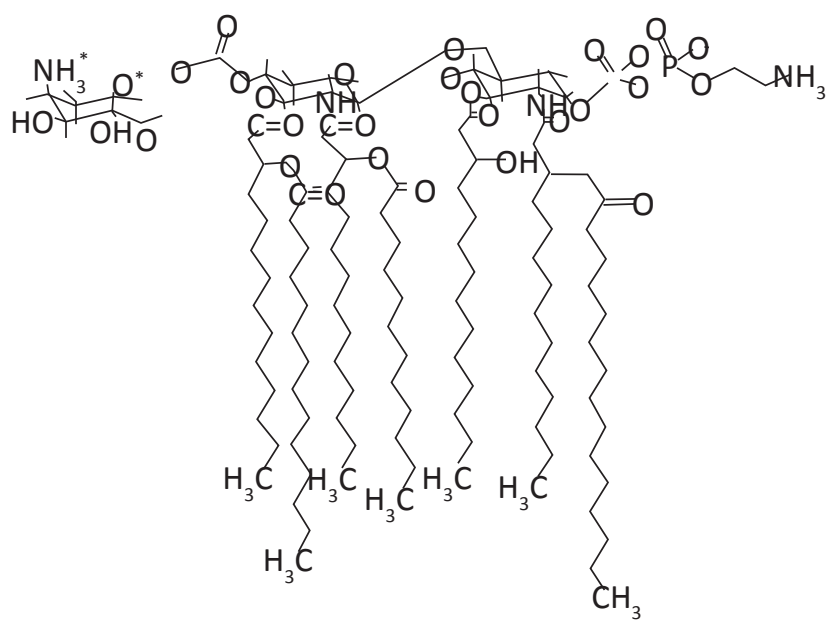

Figure 6: General structure formula of LPS endotoxins from (Funari and Testai, 2008)

\subsection{Biological Identification of algal toxins}

The initial identification of the presence of green and blue green algae depends on the water color change to green or bluish green, accumulation of algae and floating on the water surface (Joosten and Anton, 2006), also depending on chemical analyses where blue-green algae do not need specialized chemicals such as other types of nitrogen and phosphorus as a major growth factor and depend on selffeeding via photosynthesis (Madigan et al., 2003). In addition to the above, also monitoring of dead organisms in water in the cases of eutrophication such as birds and fish, gives an evidence of the presence of Cyanotoxins (Zaccaroni and Scaravali, 2008). It is now easy to define and diagnose algae of all kinds for an acceptable classification system and for all existing algae where classification is still under constant and rapid revision and for all levels and constant updating of this information as well as genetic and structural evidence (Barasanti et al., 2008).

\section{Conclusion}

Toxins cannot be proved from the surrounding conditions nor isolated from the toxic algae associated closely, that neglecting the study of toxic algae means, we have caused the annihilation of a complete environment that has provided food to many living organisms. It is not advisable to establish the foundations of a study 
without taking into consideration the recent data of high temperature and permanent pollution as emergency data on all studies. It should be noted, as well as the results of coincidence that may change the concept of study in the field of economics and food security, also medical therapies due to relation with field of human life and economic.

\section{References}

Abbasi, A., Sajid, A., Haq, N., Rahman, S., Misbah, Z., Sanober, G., Ashraf, M., Kazi, A.G., 2014. Agricultural Pollution: An Emerging Issue. In: Ahmad, P., Wani, M.R., Azooz, M.M., Tran, LSP. (Eds.). Improvement of Crops in the Era of Climatic Changes. Springer Science+Business Media New York, 347-386.

Atafar, Z., Mesdaghinia, A., Nouri, J., Homaee, M., Yunesian, M., Ahmadimoghaddam, M., Mahvi, A.H., 2010. Effect of fertilizer application on soil heavy metal concentration. Environ Monit Assess. Springer Science+Business Media B.V., 160, 83-89.

An, J., Carmichael, W.W., 1994. Use of a colorimetric protein phosphatase inhibition assay and enzyme inked immunosorbent assay for the study of microcystins and nodularins. Toxicon 32, 1495-507.

An, J., Carmichael, W.W., 1994. Use of a colorimetric protein phosphatase inhibition assay and enzyme inked immunosorbent assay for the study of microcystins and nodularins. Toxicon 32, 1495-507.

Bitton, G., 2014. Esthetic and other concerns associated with drinking water treatment and distribution. In Microbiology of Drinking Water Production and Distribution, First Edition. Chapter 5, 4-11.

Boland, M.P., Smillie, M.A., Chen, D.Z.X., Holmes, C.F.B., 1993. A unified bioscreen for the detection of diarrhetic shellfish toxins and microcystins in marine and freshwater environments Toxicon 31, 1393-1405.

Butler, N., Carlisle, J.C., Washburn, B., 2009. Microcystins: A brief overview of their toxicity and effects, with special reference to fish, wildlife, and livestock. Office of Environmental Health Hazard Assessment. OEHHA Ecotoxicology. California Environmental Protection Agency, 1-9.

Craig, M., McCready, L., Luu, H.A., Smillie, M.A., Dubord, P., Holmes, C.F.B., 1993. Identification and characterization of hydrophobic microcystins in Canadian freshwater cyanobacteria. Toxicon 31, 1541-1549.

Chauhan, R.P., Kumar, A., 2015. Soil to plant transfer of alpha activity in potato plants: impact of phosphate fertilizers. Journal of Environmental Health Science \& Engineering, 13(45), 1-9.

Conforti, P., 2011. Looking ahead in world food and agriculture: Perspectives to 2050. Agricultural Development Economics Division Economic and Social Development Department. FAO, 1-7.

Chorus, I., Bartram, J., 1999. Toxic Cyanobacteria in water: A guide to their public health consequences, monitoring and management. WHO, UNESCO, UNEP. ISBN 0-41923930-8.

Codd, G.A., Chorus, I., Burch, M., 1999. Design of monitoring programs. In: Chorus, I., Bartram, J., Toxic cyanobacteria in water: a guide to their public health consequences, monitoring and management. WHO, 302.

Chorus, I., Bartram, J., 1999. Toxic Cyanobacteria in water: A guide to their public health consequences, monitoring and management. WHO. ISBN 0-419-23930-8.

Chorus, I., 2005. Current approaches to cyanotoxin risk assessment, risk management and regulations in different countries. Federal Environmental Agency (Umweltbundesamt). P9-28.

Cires, S., Delgado, A., Gonzalez-Pleiter, M., Quesada, A., 2017. Temperature influences the production and transport of saxitoxin and the expression of sxt genes in the Cyanobacterium Aphanizomenon gracile. Toxins 9(322), 1-16.

Chong, M.W.K., Wong, B.S.F., Lam, P.K.S., Shaw, G.R., Seawright, A.A., 2002. Toxicity and uptake mechanism of Cylindrospermopsin and Lophyrotomin in primary rat hepatocytes. Toxicon 40, 205-211.

Codd, G.A. Lindsey, J., Young, F.M., Morrison, L.F., Metcalf, J.S., 2005. Harmful cyanobacteria. From mass mortalities to management measures. In: Harmful Cyanobacteria. Huisman, J., Matthijs, H.C.P., Visser, P.M. (Ed.), Dordrecht, the Netherlands: Springer, 1.

Dellinger, J., Dorevitch, S., Faustman, E., Foldy, S., Takaro, T., 2017. Human health effects of cyanobacterial toxins in the great lakes region: a science and monitoring assessment. A report submitted to the International Joint Commission by the Health Professionals Advisory Board, 10-13.

Dellinger, J., Dorevitch, S., Faustman, E., Foldy, S., Takaro, T., 2017. Human health effects of cyanobacterial toxins in the great lakes region: a science and monitoring assessment. A report submitted to the International Joint Commission by the Health Professionals Advisory Board, 10-13.

DalCorso, G., Manara, A., Piasentin, S., Furini, A., 2014. Nutrient metal elements in plants. Minireview. Metallomics. Royal Society of Chemistry 6(10), 17701788.

EEA., 2011. Safe water and healthy water services in a changing environment. Technical report. Eutrophication of Freshwater and Coastal Marine Ecosystems, 12-16.

Funari, E., Testai, E., 2008. Human health risk assessment related to Cyanotoxins exposure. Critical Reviews in Toxicology. 38, 97-125.

Falconer, I.R., Beresford, A.M., Runnegar, M.T.C., 1983. Evidence of liver

Falconer, I.R., Runnegar, M.T.C., Buckley, T., Huyn, V.L., Bradshaw, P., 1989. Use of powdered and granular 
activated carbon to remove toxicity from drinking water containing cyanobacterial toxins. Journal-American Water Works Association, 18, 102-105.

Falconer, I.R., 2005. Cyanobacterial Toxins of Drinking Water Supplies: Cylindrospermopsin and Microcystins CRC, Boca Raton, Florida.

Falconer, I.R., Humpage, A.R., 2001. Preliminary evidence for in vivo tumor initiation by oral Dministration of extracts of the blue-green alga Cylindrospermopsis raciborskii containing the toxin cylindrospermopsin Environ. Toxicol. 16, 192-195.

Falconer, I.R., Humpage, A.R., 2005. Health Risk Assessment of Cyanobacterial (Blue-green Algal) Toxins in Drinking Water. International journal environment research public health. 2(1), 43-50.

Fitzgeorge, R.B., Clark, S.A., Keevil, C.W., 1994. Routes of intoxication. In Detection Methods for Cyanobacterial Toxins (Codd, G.A., Jefferies, T.M., Keevil, C.W., Potter, E., (Eds.), 69-74. The Royal Society of Chemistry, Cambridge.

Falconer, I.R., Humpage, A., 1996. Tumour promotion by cyanobacterial toxins. Phycologia, 35, 74-79. Damage by toxin from a bloom of the blue green algae, Microcystis aeruginosa. Med. J. 1, 511-514.

Falconer, I.R., 1998. Algal toxins and human health. In The Handbook of Environmental Chemistry, vol. 5, part C, Quality and Treatment of Drinking Water II (Hrubec, J., editor). Springer, Berlin, 53-82.

Falconer, I., 1993. Algal Toxins in Seafood and Drinking Water. Academic Press, London.

Funari, E., Testai, E., 2008. Human health risk assessment related to cyanotoxins exposure. Critical Reviews in Toxicology. 38, 97-125. In ISSN: 1040-8444 print / 1547-6898 nforma Healthcare USA, Inc. Supplement 1, 113-122.

Hossain, M.Z., von Fragstien, P., von Niemsdorff, P., Heb, J., 2017. Effect of different organic wastes on soil propertie s and plant growth and yield: a review. Scientia Agriculturae Bohemica the Journal of Czech University of Life Sciences Prague 48(4), 224-237.

Holland, A., Kinnear, S., 2013. Interpreting the possible ecological role(s) of cyanotoxins: compounds for competitive advantage and/or physiological aide?. Marine Drugs 11, 2239-2258.

Hitzfeld, B.C., Hoger, S.J., Dietrich, D.R., 2000b. Cyanobacterial Toxins:removal during drinking water treatment, and human risk assessment. Environmental Health Perspectives 108 (1), 113-122.

Hindman, S.H., Favero, M.S., Peterson, A., 1975. Pyrogenic reactions during hemodialysis caused by Extramural endotoxins. Lancet 11, 732-734.

Harada, K.I., Ogawa, K., Matsuura, K., Murata, H., Suzuki, M., Watanabe, M.F., Itezono, Y., Nakayama, N., 1990a. Structural determination of geometrical isomers of
microcystins-LR and RR from cyanobacteria by twodimensional NMR spectroscopic techniques. Chemical research in Toxicology 3, 473-481.

Harada, K.I., Matsuura, K., Suzuki, M., Watanabe, M.F., Oishi, S., Dahlem, A.M., Beasley, V.R., Carmichael, W.W., 1990b. Isolation and characterization of the minor components associated with microcystins-LR and -RR in the cyanobacterium (bluegreen algae). Toxicon, 28, 55-64.

Jung, J.M., Lee, Y.J., Park, H.K., Jung, E.Y., Joo, G.J., 2003. The analysis of cyanobacterial neurotoxins by highperformance liquid chromatography-mass spectrometry. Algae 18(3), 233-238.

Jacoby, J., 2005. Toxic algae in lakes in the chambers the clover creek watershed seattle university seattle, WA. Presentation.

Joosten, A.M.T., 2006. Flora of the blue-green algae of the Netherlands. In the non-filamentous species of inland waters. Voluem 1. BRILL. KNNV Publishing, Utrecht, Netherlands.

Jones, G.J., Falconer, I.F., Wilkins, R.M., 1995. Persistence of cyclic peptide toxins in dried cyanobacterial crusts from Lake Mokoan, Australia. Environmental Toxicology and Water Quality 10, 19-24.

Khan, M.N., Mohammad, F., 2014. Eutrophication: challenges and solutions. In: Ansari, A.A., Gill, S.S. (Ed.). Eutrophication: Causes, Consequences and Control, 1-15.

Kakhia, T.I., 2011. Fertilizer Handbook. Date of chemical fertilizers. Damascus. (Syria). Chapter 1, 5-25.

Kilmer, V.J., 1979. Minerals and Agriculture. In: Trudinger, P.A., Swaine, D.J., Studies in environmental science 3. biogeochemical cycling of mineral-forming elements. ScienceDirect. Handbook. Chapter 9, 515-558.

Kurmayer, R., Dittman, E., Fastner, J., Chorus, I. 2002. Diversity of microcystin genes within a population of the toxic Cyanobacterium mycrocystis spp. in lake Wannsee (Berlin, Germany). Microb. Ecol 43,107-118.

Kurmayer, R., Dittman, E., Fastner, J., Chorus, I., 2002. Diversity of microcystin genes within a population of the toxic Cyanobacterium mycrocystis spp. In Lake Wannsee (Berlin, Germany). Microb. Ecol 43, 107-118.

Mankiewicz, J., Tarczynska, M., Walter, Z., Zalewski, M., 2003. Natural toxins from cyanobacteria. Acta Biologica Cracoviensia Series Botanica 45/2, 9-20.

Messineo, V., Bogialli, S., Melchiorre, S., Nicola, S., Luglie, A., Casiddu, P., Mariani, A.M., Padedda, B.M., DiCorcia, A., Mazza, R., Carloni, E., Bruno, M., 2009. Cyanobacterial toxins in Italian freshwaters. Limnologica-Ecology and Management of Inland Waters 39(2), 95-106.

Madigan, M.T., Martinko, JM. Parker, J., 2003. Brock biology of microorganisms (10 $10^{\text {th }}$ Edn). Upper Saddle River, New Jersey: Prentice Hall, 1019.

Norris, R.L., Seawright, A.A., Shaw, G.R., Smith, M.J., 
Chiswell, R.K., Moore, M.R., 2001. Distribution of $14 \mathrm{C}$ cylindrospermopsinin vivo in the mouse. Environ. Toxicol. 16, 498-505.

Norris, R.L., Seawright, A.A., Shaw, G.R., Senogles, P., Eaglesham, G.K., Smith, M.J., Chiswell, R.K., Moore, M.R., 2002. Hepatic xenobiotic metabolism of cylindrospermopsinin vivo in the mouse. Toxicon 40, 471-476.

Pandey, P., Pandey, P.K., Pandey, M., 2017. A review on occurance of radioactive elements in different states of India. Short Review Paper. Research Journal of Chemical Sciences 7(6), 18-22.

Patocka, J., Gupta, R.C., Kuca, K., 2011. Anatoxin-a (S): Natural organophosphorus anticholinesterase agent. Review article. Military Medical Science Letters. Voj. Zdrav. Listy 80, 129-139.

Roy, R.N., Finck, A., Blair, J.G., Tandon, H.L.S., 2006. Soil fertility and crop production. In Plant nutrition for food security. Chapter 4. A guide for integrated nutrient management. FAO, 43-90.

Rai, N., Ashiya, P., Rathore, D.S., 2014. Comparative study of the effect of chemical fertilizers and organic fertilizers on Eisenia Foetida. International Journal of Innovative Research in Science, Engineering and Technology 3(5), 12991-12998.

Runnegar, M.T., Kong, S.M., Zhong,Y.Z., Ge, J.L., Lu, S.C.. 1994. The role of glutathione in the toxicity of a novel cyanobacterial alkaloid cylindrospermopsin in cultured rat hepatocytes. Biochemical and Biophysical Research Communications 201, 235-241.

Rinehart, K.L., Namikoshi, M., Choi, B.W., 1994. Structure and biosynthesis of toxins from bluegreen algae (Cyanobacteria). Journal of Applied Phycology 6, 159-176.

Runnegar, M.T., Kong, S.M., Zhong, Y.Z., Lu, S.C., 1995. Inhibition of reduced glutathione synthesis by cyanobacterial alkaloid cylindrospermopsin in cultured rat hepatocytes. Biochemical Pharmacology 49, 219-225.

Savci, S., 2012. An agricultural pollutant: chemical fertilizer. International Journal of Environmental Science and Development 3(1), 77-80.

Smith, V.H., 2003. Eutrophication of freshwater and coastal marine ecosystems: a global problem. review articles.
Eutrophication, 1-14.

Soliakov, L., Gallagher, T., Wonnacott, S., 1995. Anatoxina-evoked [3H] dopaminerelease from rat striatal synaptosomes. Neuropharmacology 34(11), 1535-1541.

Sivonen, K., Jones, G., 1999. Cyanobacterial toxins. In: toxic cyanobacteria in water a guide to public health significance, monitoring and management. In: Chorus, Bertram, J. (Edn.), The World Health Organization. ISBN 0-419-23930-8. E and FN Spon, London, UK, 41-111.

Tisdale, E., 1931. Epidemic of intestinal disorders in Charleston, WVA, occurring simultaneously with unprecedented water supply conditions. American Journal of Public Health 21,198-200.

Tatters, A.O., Howard, M.D.A., Nagoda, C., Busse, L., Gellene, A.G., Caron, D.A., 2017. Multiple Stressors at the LandSea Interface: Cyanotoxins at the Land-Sea Interface in the Southern California Bight. Toxins 9(95), 1-17.

Velzeboer, R.M.A., Baker, P.D., Rositano, J., Heresztyn, T., Codd, G.A., Raggett, S.L., 2000. Geographical patterns of occurrence and compositions of saxitoxins in the cyanobacterial genus Anabaena (Nostocales Cyanophyta) in Australia. Phycologia 39, 395-407.

Whitton, B., 1992. Diversity, ecology and taxonomy of the cyanobacteria. In: Photosynthetic Prokaryotes. Mann, H., Carr, N. (Ed.). New York: Plenum Press, 1-51.

WHO., 2016. Protecting surface water for health Identifying, Assessing and Managing Drinking water Quality risks in Surface water catchment, 33-47.

Zaccaroni, A., Scaravali, D., 2008. Toxicity of fresh water algal toxins to humans and animals. In: Evangelista, V., Barsanti, L., Frasanito, A-M., Passarelli, V., Gualtieri, P. (Eds.), Algal toxins: nature, occurrence, effect and Detection. The NATO science for Peace and Security Series A: chemistry and biology. Springer, 45-79.

Zain, M.E., 2011. Impact of mycotoxins on humans and animals. Journal of Saudi Chemical Society 15(2), 129-144.

Zaccaroni, A., Scaravali, D., 2008. Toxicity of fresh water algal toxins to humans and animals. In: Evangelista, V., Barsanti, L., Frasanito, A-M., Passarelli, V., Gualtieri, P. (Eds.) Algal toxins: nature,occurrence, effect and Detection. The NATO science for Peace and Security Series A: chemistry and biology. Springer, 45-79. 